\title{
The Origin of Petroleum.
}

U NLIKE most problems concerning origins, which have but a philosophic. or academic interest, that of the genesis of petroleum has a distinctly practical significance, for if solved, prospectors for mineral oil would be provided with important data and chemists might learn how to produce artificially valuable substances similar to, if not identical with, natural petroleum. Man's fertile imagination has spun not only an embarrassing number of speculations and hypotheses concerning the nature of the raw material or materials from which petroleum has been derived, but also innumerable explanations of the modus operandi of its formation. Of these, only a tithe remains. Explanations that affirm a cosmic origin or postulate volcanic activity as the effective cause, have long been abandoned, and to-day there are only three which find scientific support. The least popular of these, the inorganic theory, affirms that petroleum originates from the interaction of metallic carbides, presumed to exist immediately below the earth's outer crust, and steam, whereby various hydrocarbons are formed, and these undergo further changes, including polymerisation, to produce the compounds that are found in petroleum. It has recently been suggested that the methane synthesis from carbon monoxide or dioxide and hydrogen, in the presence of a catalyst, such as vanadium or nickel, of which traces are found in petroleum, might also explain the initial formation of hydrocarbons in Nature, and the presence of methane in natural gas; but these suggestions fail to interpret the occurrence of optically-active substances in petroleum, and the presence of nitrogen in some oils, while geologists have met them with uncompromising hostility.

The views that are uppermost to-day are that petroleum is derived from either animal or vegetable substances, or from both of these sources, and the chief direct evidence supporting this organic theory is the occurrence in petroliferous strata of vegetable and animal remains, including, in a few cases, remains of bacteria. Important, if less direct, testimony is the presence in petroleum of the optically-active substances cholesterol and phytosterol, which are characteristic constituents of animals and plants, respectively. The various elaborations of this view are mainly concerned with the nature of the chemical reactions involved, and how they are influenced by the three determining factors of pressure, temperature, and time ; it is, however, not easy to formulate any one hypothesis to explain the formation of such complex mixtures as mineral oils, and still more difficult to account for the great diversity in chemical composition exhibited by mineral oils from different localities.

The evidence admitted by those who believe in a purely animal origin includes the statements: that petroleum found in primary rocks is much more often accompanied by animal than by vegetable remains; that formations containing only plants are not bituminous; that mixtures of hydrocarbons similar to those found in petroleums can be made artificially from animal fats, and that such production can be observed in Nature to-day, notably in the coral reefs and lagoons of Djebel Zeit in Egypt. The scarcity of animal fossils in petroliferous strata is explained by assuming that the fauna were either skeletonless, or, if not, their calcareous coatings were dissolved by the carbon dioxide liberated during their decomposition. Advocates of the vegetable origin doubt if the supply of animal matter has been sufficient for the purpose, plants being much more plentiful than animals; they comment on the absence of phosphatic deposits from the vicinity of oilfields; and many trace relationships between coals and petroleum.

Mr. E. H. Cunningham-Craig is one of the foremost supporters of the purely vegetable theory, and in opening the discussion on the origin of petroleum, held by the Institution of Petroleum Technologists in London on October 9 , he brought forward evidence in its favour derived from recent researches. Geological evidence is accumulating in support of the view that coals and lignites are related to petroleum. Thus, in Trinidad, the three main oil-bearing horizons have each a carbonaceous phase in some other district, and the petroliferous and carbonaceous phases approach each other very closely in some localities. Similar evidence is found in Venezuela, Burma, Assam, Hungary, and Rumania. The D'Arcy well, near Dalkeith, was drilled on the assumption that oil-shale deposits represent petroleum that is " dead and buried," and therefore that free petroleum might be found beneath the oilshale series; actually it was discovered below the oilshale at each of two predicted depths. Dr. F. Bergius, of Heidelberg, has hydrogenised coal by heating it in free hydrogen in an autoclave at very high pressures and at temperatures up to $455^{\circ} \mathrm{C}$. As the result of an exothermic reaction, a liquid was obtained that was " almost identical with crude petroleum." The determining factors of the formation were the proportion of volatile matter in the coal and the pressure. Nature, it is thought, may act in a similar way, but more slowly and at lower temperatures, on vegetable matter before it has reached the coal stage, i.e. while it still contains much hydrogen in proportion to carbon.

Supporters of the animal theory, said Mr. CunninghamCraig, should endeavour to repeat Dr. Bergius's experiments with animal matter in place of vegetable. Cannel coals yield most oil on distillation; they contain much inorganic matter and are not highly carbonised. Torbanites also give high yields of oil and are to be regarded as cannels containing colloidal inqrganic matter which has been heated in a natural autoclave. In this process it is assumed that the oil liberated from the torbanite combines with the colloidal inorganic matter to form the gels that can be seen in the microscope; but the conversion into petroleum has not been complete owing to partial carbonisation. Prof. A. E. Flynn has separated and investigated the gels occurring in torbanite from Nova Scotia, and has proved conclusively that they are not vegetable fossils ; so that if oil-shale is petroleum "dead or buried," torbanite is petroleum "still-born."

Mr. Cunningham-Craig's paper met with many criticisms, both from the chemists, led by Dr. A. E. Dunstan, and from the geologists, led by Mr. Dewhurst. Dr. Dunstan raised obstacles to more than one theory; for example, he cannot admit that the laboratory methods of producing hydrocarbons from fatty acids NO. 28 I 7, vOL. II2] 
are applicable in Nature, and it is difficult to see why the molecules of such acids occurring in ratural fats and containing even numbers of carbon atoms should give rise to molecules present in petroleum which contain both odd and even numbers of carbon atoms. He has analysed many times the liquids obtained from coal by the Bergius method, and has found that their similarity to petroleum is very remote. How can the presence of benzene, toluene, and xylene in certain petroleums be explained? Is it not probable that there are several modes of origin ? Light is required on the origin of the vast amounts of methane present in natural gas. What happens to the nitrogen and phosphorus contained in animal organisms? Why is iodine so scarce in petroleum?. Mr. Dewhurst said that petroleum found in the Upper Silurian was much earlier than the earliest vegetation, and earlier than the coal found in the Late Devonian. Palæozoic oil was probably formed from any organic matter available, and there were two distinct types of oilfield : the lignitic, of vegetable origin, which was deposited in areas where the climate was moist, and oilfields of marine animal origin, which are found associated with deposits of salt, gypsum, etc., and were formed in deltas that were cut off later from the mainland.

The discussion generally was suggestive and served its purpose in crystallising thought around important nuclei. If it did not bring nearer a definitive solution of the problem, it at least showed how far we have progressed since the time when a Polish cleric, named Kluk, traced the origin of petroleum to the Garden of Eden, which was so fertile that it must have contained fats ; at the Fall this fat partly volatilised and partly sank into the earth, where it was finally transformed into mineral oil by the changes induced by the Flood. Truly, a science progresses by changing its points of view.

\section{Obituary.}

Dr. Herbert McLeod, F.R.S.

$\mathrm{D}^{\mathrm{n}}$ R. HERBERT McLEOD, who died on October 3 , was born at Stoke Newington on February 9, I84I, and was the son of Mr. Bentley McLeod. He was educated at Stockwell Grammar School. In I860 he became lecture assistant to Prof. A. W. Hofmann at the Royal College of Chemistry. Former students of this College never forget the brilliant way in which McLeod carried out the experiments shown at the lectures. Hofmann was so impressed by his ability that he arranged that, in addition to acting as his assistant, McLeod should take the entire College curriculum. He worked with Hofmann on aniline dyes and had a part in the discovery of magenta. McLeod accompanied Hofmann to Berlin. A little later he returned to the Royal College of Chemistry as assistant to Prof. Frankland. At this period he published papers on acetylene, on a new form of aspirator, and, in conjunction with Frankland, a Report to the British Association on the determination of the gases in well-waters.

In 187 I McLeod was appointed professor of experimental science (afterwards chemistry) at the Royal Indian Engineering College, Cooper's Hill. He held this post till I90I. In I 876 he published a description of "An Apparatus for Measurement of Low Pressures of Gases." The McLeod gauge described in this paper is now commonly used. A little later, in 1878 , McLeod published, in conjunction with G. S. Clarke (now Lord Sydenham), a paper on "Some Figures exhibiting the Motion of Vibrating Bodies and on a new Method for Determining the Speed of Machines." The method, developed in this and in later papers on the subject, has since led to most important applications. He devised a sunshine recorder and took a keen interest in meteorology, making daily observations at 9 A.M. and 3 P.M. over a period of twenty years.

A visit paid by the late Lord Salisbury to the Royal College of Science led him to invite McLeod to co-operate with him in scientific experiments. Week-end visits to Hatfield House were frequent until Lord Salisbury became Prime Minister. Some account of these experiments was given in the obituary notice of Lord Salisbury which McLeod wrote for the Royal Society.
From I888 onwards McLeod had been reading proofs of the Royal Society's Catalogue of Scientific Papers. After the death of Mr. George Griffith in May I902, McLeod undertook the direction of this Catalogue. His chief work upon the Catalogue was the preparation of a subject-index to all scientific papers published between 1800 and I900. All the index slips necessary for this. work were prepared under his direction, and the volumes for mathematics, mechanics, and physics were published. The author Catalogue for $1883^{-1900}$ was also under his charge, and he had seen half of this through the press when, in 1915, he was obliged, through ill-health, to give up active work.

McLeod was honorary LL.D. of St. Andrews, was elected a fellow of the Royal Society in I88I, and was president of the Chemical Section of the British Association at Edinburgh in 1892 . He became a fellow of the Chemical Society in I868 and served on its council in $1871-74$, and again $1880-84$. He was vice-president of the Chemical Society in $1887-90$, and again I90I-4. He served on the Council of the Royal Society in $1887-89$.

\section{Dr. Arthur A. Rambaut, F.R.S.}

ARthUR Alcock Rambaut, Radcliffe Observer at Oxford, who died at a nursing home on October I4, after a prolonged illness, was born at Waterford on September 2I, 1859, and was a son of the Rev. E. F. Rambaut. At Trinity College; Dublin, he won a first science scholarship in 1880 and took his degree the following year as senior moderator and gold medallist in mathematics and mathematical physics. Having spent some time as senior science master at the Royal School, Armagh (where he had been educated himself), he was in 1882 appointed assistant at the Dublin University Observatory at Dunsink under Sir Robert Ball. He had charge of the transit circle and observed regularly with it for about eight years, the results being published in Parts VI. and VII. of the "Astronomical Observations and Researches made at Dunsink." This work was laid aside when Mr. Isaac Roberts presented the observatory with a 15 -inch reflector, with which some of his earliest work in astronomical photography had been made. Rambaut 